\title{
The Effect of Using Language Games on Vocabulary Retention of Iranian Elementary EFL Learners
}

\author{
Marzieh Taheri \\ English Language Department, Islamic Azad University, Savadkouh Branch, Iran
}

\begin{abstract}
The present study aimed at investigating the effect of using language games on elementary students' vocabulary retention. Thirty two numbers of students were chosen. They were at the same level of proficiency and were assigned into two groups of 16. The control group received traditional method of teaching vocabulary such as: drills, definitions, etc. and the experimental group was exposed to language games as a treatment. The treatment of the study took four weeks, one session every week. After the treatment, posttest 1 was administered to both groups in order to investigate the students' immediate vocabulary learning in two different conditions, with and without language games. After two weeks posttest 2 was administered to both groups to determine the delayed effect of learning again with and without the treatment. Four weeks after the second posttest -six weeks after the completion of the course- the third posttest was administered to determine the participants' ability of retention in both groups. Analyzing the data revealed that the effect of the gamelike activities was more significant in the delayed time than the immediate one.
\end{abstract}

Index Terms-language games, cooperative learning, retention

\section{INTRODUCTION}

One of the most important issues in second language teaching and learning is vocabulary learning and perhaps one of the most difficult aspects of learning a second language is the retention of learned vocabularies (Holden, 1999).

What is the best way to teach vocabulary has always been one of the controversial issues in language teaching (Coady\& Huckin, 1997). Teachers always disagreed about how to include vocabulary teaching in their instructional programs. According to Hatch and Brown (1995), there are numerous types of approaches, techniques, exercises and practice that can be used to teach vocabulary, but teachers should decide what types would be best for their students and their circumstances. In this regard, Rivers (1981) mentioned:

"as language teachers, we must arouse interest in words a certain excitement in personal development in this area... we can help our students by giving them ideas on how to learn vocabulary and some guide on what to learn" (p. 463).

Rivers (1981) further added that in order to decide which technique to use, the teacher should see whether the chosen technique a) achieves the objectives, b) maintain the interest and enthusiasm of the learner and c) suits to all types of students.

Some researchers such as Nguyen and Khuat (2003) and Uberman (1998) have shown that students are tired of learning vocabulary in traditional methods such as rehearsing, writing words on papers or learning passively through teacher's explanations, and this has created severe problems with learning skills. Nguyen and Khuat (2003) believe Students prefer to learn language in a relaxed environment such as vocabulary games. They believe that in an interesting and communicative class learners can learn 80 percent of what they exposed to.

According to Freeman (1986), learners enjoy language games they enjoy communicative involvement in the classroom. He believes that games can provide a healthy and constructive competition. Games can encourage learners discovering and voluntary involvement to the learning process, it can also establish a better bonding between teacher and learners. Finally a good designed language games can create a real communication context in the classroom which can help learners to improve their speaking ability.

\section{LITERATURE REVIEW}

Although vocabulary teaching and learning were ignored, to a great extent, in certain methods of language teaching for some decades, there is now a widespread agreement upon the need for language learners to improve their knowledge of vocabulary (Coady and Huckin, 1997). Channell (1998) stated that vocabulary teaching should be viewed as a separate area in teaching a foreign language because vocabulary is vital for improving language proficiency. Also Carter (1992, pp. 152-153) found "the need for much more vocabulary to be taught and learned as a separate activity rather than, say, part of a grammar or reading lesson".

Laufer (1997) also argues that if fluency is understood as the "ability to convey a message with ease and comprehensibility", then vocabulary adequacy and accuracy matter more than grammatical correctness. According to 
Freeman (1986) language games have real life communication features because the players are required to exchange ideas with each other and also they will have the opportunity to receive immediate feedback from their playmates and also their teacher. "Games can lower anxiety, this making the acquisition of input more likely" (Richard, Amato, 1988, p. 147). According to Hansen (1994) one of the advantage of the language game is that it can provide opportunity for shy students to involve voluntarily in classroom activities.

Lee (1996) lists some advantages of language games such as "a welcome break from the usual routine of the language class", "motivating and challenging", "effort of learning" and "language practice in the various skills" (p. 35).

Abdikhah (1998) states from the psychological point of view, games have many benefits. They can reduce inhibition of the learners especially if they are cooperating in the games not competing. The shy and timid students who do not show any tendency to participate in class works will feel more at ease and will participate more freely. According to Nguyen and Khuat (2003), using games provides a relax and fun environment for learners, therefore, help them to learn better. They believe learners interested in friendly competition which motivate them to voluntarily involvement in the classroom tasks.

\section{Methodology}

\section{A. Purpose and Significance of the Study}

Learning vocabulary is a part of learning any language, one should think of the way to achieve that goal. The traditional methods for learning unknown vocabularies have not been so successful and students as well as teachers are tired of the routine ways of teaching words. Learners also tend to be autonomous in their learning and they want to have control in their leaning.

Thus this study tries to help access better ways of learning and retaining words. One way is reinforcing vocabulary through games which helps learners develop and use words in different contexts. By using language games students can get rid of boring classrooms.

It should be noted that long-term retrieval of learned vocabularies is very important, so the delayed as well as the immediate effects are factors which will be tested in this study to know if game-like activities are superior to traditional non-communicative activities in the long-term retrieval of vocabulary items. This gains significance because all attempts should consider recalling vocabulary in the long run otherwise it is useless to try to figure out the best ways to teach vocabulary since long-term recall acts as an indispensible part of learning vocabulary.

Also applying language games in class has pedagogical applications for students, teachers and text book developers. Teachers can use game as "teaching device". They find game as an interesting activity to attract students to learning process also rejecting some teachers' opinions regarding "game" as time-killing activity. As well as teachers, students benefits from language games. Students feel comfortable communicating their peers therefore there would be a sound competition among them. Finally, text book developers can select and integrate various types of the games in the syllabus of the course books.

Therefore, the present study aims to answer the following research question:

Does using language games have any significant effect on vocabulary retention of Iranian elementary EFL learners?

\section{B. Participants}

The total number of participants was 32 female students, selected from among language learners at a private Language Institutes in Iran, Sari ranged from 11 to16 years old. Based on the institutes' placement test, students who were enrolled at elementary level class were selected for the study.

\section{Instrumentations}

In this study four instruments were used: a homogenizing test and three vocabulary tests. A nelson English language test was administered to both group to make us sure that all of the participant are at the same level of proficiency. The reliability of the homogenizing test was .82 according to Kuder-Richardson 21 formula. Three vocabulary tests, each of them included 20 multiple-choice items. The first vocabulary test was considered as the immediate posttest to check the participants' short term learning. The reliability of the first posttest was .71 according to Kuder-Richardson 21 formula. The second and the third vocabulary tests were administered in order to measure the groups' vocabulary long term recall. The reliability of the tests according to Kuder- Richardson 21 was .76 and .73 for posttest 2 and 3 respectively. The total score of each of the vocabulary tests was 20, since each test had 20 items; one point was given to each item. So the scores of the test were between 0 and 20. These tests were piloted on the elementary level in another institute and the IF \& ID of this test were already done by the institute administrators, they had optimal IF \& ID.

\section{Procedure}

At first, Nelson English language test consist of 50 multiple choice item was administered to three different elementary level classes in order to homogenizing the participants. This was done by calculating the descriptive statistics of the data. Thirty two participants whose score was two standard deviation above and below the mean were selected for the study. The selected students were randomly divided into control and experimental group. As the whole number of students chosen were thirty two, so two groups of sixteen participants were assigned. 
In order to select unfamiliar vocabularies, sixty five elementary level words were given to both groups. The participants were asked to underline the familiar words and write down their Persian equivalent. There were fifty two words which learners could not recognize their meaning. So these words were selected for the study. Since the participants didn't familiar with the selected words, the scores of participants were zero before the treatment in the both groups.

Both groups learned 52 new vocabularies in 4 sessions each session 13 new words. Students in experimental groups were exposed a game every session. Four games were used: the definition game, half a crossword, cross them out, making sentences. Every session, according to the need of the game the researcher divided the students (experimental group) into the groups of 2,3 , etc. then she explained clearly the rules and the time of the game to the groups to that all the participants know well what they are going to do.

Each game had its own special characteristics so that the students had to act differently in each game. For example: The Half a Crossword game. The teacher divided the participants into two groups of eight. Every group had a crossword which half of it was filled with the information which was unknown to the other group. Then the students in a group helped the other groups to find the intended word and fill the puzzle, through definitions, making examples, etc. while the other group discussed and cooperated with each other to find the intended word. It was interesting that everyone in the group had some information about the intended word so all of them attended in the game to help the other group recognize the word. Finally if the group could not find the word in the determined time (e.g. five minutes), it lost a point and the other group announced the intended word. The group with the most points was winner. In fact the students attended in a friendly competition and the researcher wrote their results on the board and announced the winners and the losers.

The control group learned the new words through traditional method of vocabulary teaching such as definition, synonyms, antonyms, drills, doing fill-in-the- blanks etc.

At the end of the treatment the first post test was held to find out whether teaching English vocabulary through gamelike activities are superior to more traditional from focused method of teaching, in an immediate time. The result was obtained. Two weeks after the second posttest was held to find out whether teaching English vocabulary through gamelike activities are superior to more traditional from focused method of teaching, in a delayed time. And four weeks after the second posttest, the third posttest was given to investigate the long term vocabulary recall in both groups. The data were collected in the three posttests to compare the groups' scores.

\section{RESULTS}

\section{A. Results of the Homogenizing Test}

At the beginning of the study, the researchers administered a Nelson test to 45 participants. This test was administered to homogenize the participants; its results are indicated in the following tables:

\begin{tabular}{|c|c|c|c|c|}
\hline \multicolumn{5}{|c|}{ Statistics } \\
\hline & & $\begin{array}{l}\text { group } 1 \text { in } \\
\text { nelson test }\end{array}$ & $\begin{array}{l}\text { group } 2 \text { in } \\
\text { nelson test }\end{array}$ & $\begin{array}{l}\text { group } 3 \text { in } \\
\text { nelson test }\end{array}$ \\
\hline \multirow[t]{2}{*}{$\mathrm{N}$} & Valid & 14 & 19 & 12 \\
\hline & Missing & 5 & 0 & 7 \\
\hline \multicolumn{2}{|c|}{ Mean } & 34.2857 & 34.2105 & 33.9167 \\
\hline \multicolumn{2}{|c|}{ Std. Error of Mean } & 2.63832 & 2.41895 & 2.98343 \\
\hline \multicolumn{2}{|c|}{ Median } & 33.5000 & 37.0000 & 37.0000 \\
\hline \multicolumn{2}{|c|}{ Mode } & 21.00 & 45.00 & 19.00 \\
\hline \multicolumn{2}{|c|}{ Std. Deviation } & 9.87170 & 10.54398 & 10.33492 \\
\hline \multicolumn{2}{|c|}{ Variance } & 97.451 & 111.175 & 106.811 \\
\hline
\end{tabular}

\begin{tabular}{|l|r|r|r|r|}
\hline & One-Sample Statistics \\
\hline & $\mathrm{N}$ & Mean & Std. Deviation & $\begin{array}{c}\text { Std. Error } \\
\text { Mean }\end{array}$ \\
\hline group 1 in nelson test & 14 & 34.2857 & 9.87170 & 2.63832 \\
group 2 in nelson test & 19 & 34.2105 & 10.54398 & 2.41895 \\
group 3 in nelson test & 12 & 33.9167 & 10.33492 & 2.98343 \\
\hline
\end{tabular}

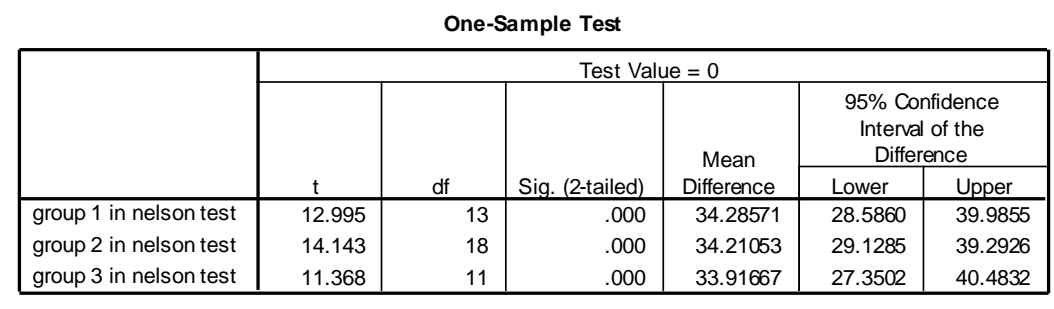


As we can see in the tables, 32 participans were selected for the study, five participants in class 1 and seven participants in class 3 whose scores were two stsndard deviation above and below the mean were ommited from the study.

\section{B. Results of the Posttests}

Statistics

\begin{tabular}{|c|c|c|c|c|c|c|c|}
\hline & & $\begin{array}{l}\text { exp group in } \\
\text { post test } 1\end{array}$ & $\begin{array}{l}\text { control group } \\
\text { in post test } 1\end{array}$ & $\begin{array}{l}\text { exp group in } \\
\text { post test } 2\end{array}$ & $\begin{array}{l}\text { control group } \\
\text { in post test } 2\end{array}$ & $\begin{array}{l}\text { exp group in } \\
\text { post test } 3\end{array}$ & $\begin{array}{l}\text { control group } \\
\text { in post test } 3\end{array}$ \\
\hline \multirow[t]{2}{*}{$\mathrm{N}$} & Valid & 16 & 16 & 16 & 16 & 16 & 16 \\
\hline & Missing & 0 & 0 & 0 & 0 & 0 & 0 \\
\hline \multicolumn{2}{|c|}{ Mean } & 16.0000 & 14.2500 & 15.6875 & 12.1875 & 15.0625 & 10.7500 \\
\hline \multicolumn{2}{|c|}{ Std. Error of Mean } & .75829 & .70415 & .81506 & .43987 & .72151 & .47871 \\
\hline \multicolumn{2}{|c|}{ Median } & 16.0000 & 14.0000 & 15.0000 & 12.5000 & 15.0000 & 11.0000 \\
\hline \multicolumn{2}{|c|}{ Mode } & $15.00^{\mathrm{a}}$ & $14.00^{\mathrm{a}}$ & 15.00 & $10.00^{\mathrm{a}}$ & $14.00^{\mathrm{a}}$ & $10.00^{\mathrm{a}}$ \\
\hline \multicolumn{2}{|c|}{ Std. Deviation } & 3.03315 & 2.81662 & 3.26024 & 1.75950 & 2.88603 & 1.91485 \\
\hline \multicolumn{2}{|c|}{ Variance } & 9.200 & 7.933 & 10.629 & 3.096 & 8.329 & 3.667 \\
\hline
\end{tabular}

a. Multiple modes exist. The smallest value is shown

According to the above tables, the mean of the control group is 14.25 and the mean of the experimental group is 16 in posttest 1. It shows that the experimental group was superior to the control group in posttest 1.

In order to check the participants' ability of the retention of vocabulary after a period of time another posttest was administered after two weeks The mean scores for the posttest 2 of the groups were 15.69 and 12.19 for experimental and control group respectively, which shows a decrease from posttest 1 to posttest 2 for both groups but the decrease was higher for control group.

The mean scores of the groups in the posttest 3 were 15.6 for experimental and 10.75 for the control groups. The results of the third posttest shoes the decrease in the means of both groups and again the decrease was less for experimental group. It shows that the control group lost most of their vocabulary knowledge over time but the experimental group did not.

INDEPENDENT SAMPLE $T$-TEST FOR POSTTEST 1

\begin{tabular}{|c|c|c|c|c|c|c|c|c|}
\hline & \multicolumn{8}{|c|}{$t$-test for Equality of Means } \\
\hline & \multirow[t]{2}{*}{$\mathbf{t}$} & \multirow[t]{2}{*}{ df } & \multirow[t]{2}{*}{ Sig. } & \multirow[t]{2}{*}{$\begin{array}{l}\text { Mean } \\
\text { Differences }\end{array}$} & \multirow[t]{2}{*}{$\begin{array}{l}\text { Std. Error } \\
\text { Differences }\end{array}$} & \multicolumn{3}{|c|}{$\begin{array}{l}95 \% \text { Confidence Interval of the } \\
\text { Differences }\end{array}$} \\
\hline & & & & & & & lower & upper \\
\hline Equal variances Assumed & 1.69 & 30 & .102 & 1.75 & .06 & loilioio & -.36 & 3.86 \\
\hline $\begin{array}{l}\text { Equal variances not } \\
\text { assumed }\end{array}$ & 1.69 & 30 & .102 & 1.75 & .21 & & -.37 & 3.87 \\
\hline
\end{tabular}

The above table shows the independent sample $t$-test of the posttest 1.The $t$-observed value was 1.69 . This amount of $t$-value was lower than critical $t$-value, (2.02), therefore the difference between two means of groups obtained from the first posttest in not statistically significant, indicating the fact that two groups were not very much different at posttest 1 . The sample $t$-test for equality of means shows that significant value was .102 which is greater than $\mathrm{p}=.05$, so there was no significant difference between the two groups in posttest 1 .

INDEPENDENT SAMPLE $T$-TEST FOR POSTTEST 2

\begin{tabular}{|c|c|c|c|c|c|c|c|c|}
\hline & \multicolumn{8}{|c|}{$t$-test for Equality of Means } \\
\hline & \multirow[t]{2}{*}{ t } & \multirow[t]{2}{*}{ df } & \multirow[t]{2}{*}{ Sig. } & \multirow[t]{2}{*}{$\begin{array}{l}\text { Mean } \\
\text { Differences }\end{array}$} & \multirow[t]{2}{*}{$\begin{array}{l}\text { Std. Error } \\
\text { Differences }\end{array}$} & \multicolumn{3}{|c|}{$\begin{array}{l}\text { 95\% Confidence Interval of the } \\
\text { Differences }\end{array}$} \\
\hline & & & & & & & lower & upper \\
\hline $\begin{array}{l}\text { Equal variances not } \\
\text { assumed }\end{array}$ & 4.98 & 30 & .000 & 4.31 & .24 & & 2.53 & 6.09 \\
\hline
\end{tabular}

INDEPENDENT SAMPLE $T$-TEST FOR POSTTEST 3

\begin{tabular}{|c|c|c|c|c|c|c|c|c|}
\hline & \multicolumn{8}{|c|}{$t$-test for Equality of Means } \\
\hline & \multirow[t]{2}{*}{$\mathbf{t}$} & \multirow[t]{2}{*}{ df } & \multirow[t]{2}{*}{ Sig. } & \multirow[t]{2}{*}{$\begin{array}{c}\text { Mean } \\
\text { Differences }\end{array}$} & \multirow[t]{2}{*}{$\begin{array}{l}\text { Std. Error } \\
\text { Differences }\end{array}$} & \multicolumn{3}{|c|}{$\begin{array}{l}\text { 95\% Confidence Interval of the } \\
\text { Differences }\end{array}$} \\
\hline & & & & & & & lower & upper \\
\hline Equal variances Assumed & 3.78 & 30 & .001 & 3.5 & .38 & Loilioio & 1.60 & 5.39 \\
\hline $\begin{array}{c}\text { Equal variances not } \\
\text { assumed }\end{array}$ & 3.78 & 30 & 001 & 3.5 & .38 & & 1.58 & 5.41 \\
\hline
\end{tabular}

The $t$ - observed values were 3.87 and 4.98 in the posttest 2 and posttest 3 respectively. This amount of $t$-value was higher than the critical $t$-value, (2.02), The sample $t$-test for equality of means shows that significant value was .001 in both posttest 2 and 3 , which is less than $\mathrm{p}=.05,(\mathrm{P}=.008<.05 .79)$, so there was a significant difference between the two groups in post-test 2 and 3. Therefore, participants in experimental group outperformed those in control group. 


\section{DISCUSSION}

This study tries to find out whether language games are useful techniques in English vocabulary teaching in Iranian learners. Social interaction in game-like activities provides the students opportunities to get help and support, let them participate in authentic communication, cooperate with each other, increase their self-esteem, show a greater willingness to interact with their peers.

Regarding this study, while student are interacting with each other in a vocabulary game they have mutual orientations to achieve a goal which is finding the new word and defeating the other group. In fact they are unconsciously motivated towards cooperating and consulting (speaking each other and using vocabulary and phrases) to win against the other group. Even weak students are engaged in the activity because there is no need to be afraid of grades and teacher just monitors students and announces the winners and losers. Students' attempts in finding the correct answer in a vocabulary game engage them in a social interaction. Interacting in vocabulary game-like activities, students are removed from nervous pressures of being observed so their ability to learn and recall vocabulary items will be increased. Students of the groups try to discover the unknown vocabulary items by negotiating each other which automatically increases students' cooperation. These outcomes are highly valued by constructivist theorists, who believe that social interaction is critical to learning.

Game is one of those activities which include all the mentioned conditions. Many students learn best when they are not encountering a direct or explicit teaching. They are most interested in being involved in accomplishing something via the language and therefore have a personal interest in the outcome of what they are using the language to do.

In learning vocabulary through language games, peers have opportunities to pursue common goal which is finding the exact vocabulary item that is merely known by one student whom helps his/her peers when they are at the zone of proximal development (students in a group have information about the intended meaning but they don't know the exact word). People in a group have different ideas about the entity of the intended word but they help (scaffold) each other and reach consensus through discussion.

All the mentioned points imply that games are beneficial in language learning, while traditional from-focused are not that most effective because they lack some features of the game. Some of them are mentioned below.

Traditional classroom activities mostly emphasize grammar rules (forms). Teacher in these classes imagine that learning the grammar is equated with learning the language while students are not pleased with grammar. But in communicative approaches such as games, the emphasis is on the meaning and students feel free to interact.

Most of the traditional classroom activities consist of many drills which emphasize accuracy and consume a lot of time but communicative activities develop communication skills which stress fluency.

The teacher governing the traditional classroom activities corrects students' mistakes when they've made it but in communicative approach it is believed that students should comminute each other. They claim when students are able to communicate, their mistakes will be corrected automatically.

Finally in classes conducting mainly through traditional beliefs in learning, teachers are the sole knowledgeable person who decide what and how activities should be done in class, ignoring students' capabilities, interests, needs, etc. but in communicative- based classes, teachers just monitor the class while caring students not spoil the class. Teacher involves students in class, caring they needs, interests, etc. and students are comfortable drawn to the learning.

All this points imply that language games are superior to the traditional methods of teaching. But it should be clarified whether there is different between language games and traditional methods of teaching vocabulary, in retention. According to Nation (2001):

A word may be noticed and its meaning comprehended in the textual input to the task, through teacher explanation or dictionary use. If that word is subsequently retrieved during the task then the memory of that word will be strengthened (p.69).

According to this theory, students should practice the learned materials; otherwise, they will easily fade away. Haycraft (1978) claims that "a large variety of word games that are 'useful for practicing and revising vocabulary after it has been introduced" (citied in Uberman, 1998).

The result of this study which confirm Nation's theory have shown that language games are suitable means for teaching vocabulary and they are effective techniques helping students' retention and cause them recall vocabulary items for a longer time.

\section{CONCLUSION}

What has been concerned in this research was whether or not using language games can make any effect on the improvement of elementary EFL Iranian learners' vocabulary retention.

To assure and determine any significant change on the improvement of our groups of subjects after receiving treatment, the results of performance of each group were analyzed at the three posttests.

It revealed that the vocabulary knowledge of the both groups improved after four sessions of instruction and although the improvement in the experimental group was higher than the control group but the difference between groups was not very significant. Analyzing the results of the delayed posttests showed that the vocabulary knowledge of both groups decreased from posttest 1 to posttest 2 and 3 but the decrease was greater in the control group. It means that the 
participants in the experimental group were able to recall the vocabularies more than control group over time. In other words, it can be concluded that using language games has very significant effect in vocabulary retention and recall of the participants. In addition, the results of posttests enabled the researcher to reject the null hypothesis and therefore the research question was answered appropriately.

\section{REFERENCES}

[1] Abdikhah, SH. (1998). "The effect of language games on vocabulary improvement". Unpublished MA thesis, Tehran: Tarbiat Modarres University.

[2] Carter, R. (1992). "Teaching English to speakers of other languages". Edited by carter, R \& D. Nunan (2001) Cambridge University Press.

[3] Channell, J. (1988) Psycholinguistic consideration, in/; R. Carter \& M. Mc Carthy (Eds) Vocabulary and language teaching (pp. 83-97). London, Longman.

[4] Coady, J. \&. Huckin, T. (1997). Second language vocabulary acquisition. Cambridge: Cambridge University Press. Freeman.

[5] D.L. (1986). Teaching and principles in language teaching (pp. 123-138). Oxford: Oxford University Press.

[6] Hansen, F. A. (1994). Testing Testing: Social Consequences of the Examined Life. University of California Press, California.

[7] Hatch, E. \& Brown. C. (1995). Vocabulary, semantic and language education. Cambridge: Cambridge university press.

[8] Holden, W.R (1999). Learning to learn: 15 vocabulary acquisition activities. Modern English Teacher, 8(2), 42-47.

[9] Laufer, B. (1997). What's in a word that makes it hard or easy: Some intra-lexical factors that affect the learning of words. In N. Schmitt., \& M. McCarthy (Eds.), Vocabulary: Description, acquisition and pedagogy (pp. 140-155). Cambridge: CUP.

[10] Lee, J.M. (1996). English Games. The People Publisher, Seoul.

[11] Nation, I. S. P. (1990). Teaching and Learning Vocabulary. Cambridge University Press, Cambridge.

[12] Nation, I. S. P. (2001). "Learning vocabulary in another language" (pp. 60-69). $8^{\text {th }}$ ed. Cambridge University Press.

[13] Nation, I. S. P. (2006). Learning vocabulary in another language. Cambridge: Cambridge University Press.

[14] Nguyen and Khuat, Learning Vocabulary through Games. Asian EFL Journal. December 2003. http:/www.asian-efljournal.com/ dec-03-sub.Vn. php.

[15] Richard-Amato, P. (1988). Making It Happen: Interactions in the Second Language Classroom. Longman, New York.

[16] Richards, J. C. \& Renandya, W. A. (2002). Current research and practice in teaching vocabulary. In J. Richards \& W. A. Renandya (eds.), Methodology in language teaching. Edinburgh, UK: Cambridge University Press, 257-267.

[17] Rivers, W. (1981). Teaching foreign long skills. (s n d. ed.) Chicago: The University of Chicago.

[18] Sadoski, M. \& Pivio, A. (2004). A dual coding theoretical model of reading. Theoretical models and processes of reading $\left(5^{\text {th }}\right.$ ED) (pp. 1329-1362).

[19] Uberman, A. (1998). "The use of games for vocabulary presentation and revision", English Teaching Forum, 36(1), $253-285$.

[20] Zimmerman, C. B. (1997). Do reading and interactive vocabulary instruction make a difference? An empirical study. TESOL QUARTERLY, 31(1), 121-140.

Marzieh Taheri is an MA graduate student in TEFL at University of Garmsar, Iran. She was born in Mazandaran, Iran. She received her BA in English translation in 2007 from Qaemshahr University, Mazandaran, Iran. She is currently teaching English in schools, Azad and Payam-e- nur universities in Mazandaran. Her area of interest includes language teaching and learning techniques and strategies. 